\title{
Exploring Consumer Behavior for App-based Food Delivery in Bangladesh During COVID-19
}

\author{
Mohinur Akter ${ }^{1}$ and Nadia Afroze Disha ${ }^{2}$
}

\begin{abstract}
The COVID-19 pandemic has engendered a new era throughout the globe in which online food delivery apps have become a significant aspect of an individual's everyday life. This study intends to probe into the nature and patterns of consumer behavior with regard to using online food delivery services during the pandemic. While most of the existing studies focus on the general aspects of consumer behavior regarding food delivery apps, this paper aims to understand what factors motivated consumers in Bangladesh to behave in certain patterns while deciding to or not to avail app-based food delivery services during a major global crisis. Data have been collected from both primary and secondary sources, with 552 participants responding to a structured questionnaire. The study revealed that a moderately large group of people used food delivery apps, especially between June and August, by placing their trust in the food delivery companies, the restaurants and the deliverymen while the rest of the population was not as confident. The minds of the second group of consumers were heavily shrouded in uncertainty regarding whether the deliverymen, restaurants or delivery companies could be trusted with following all the required safety precautions while providing their service. In future, the findings of this study will, therefore, help the food delivery companies and the restaurants to understand the importance of adopting and following stricter health and safety measures to avoid losing business during a global pandemic.
\end{abstract}

\author{
ARTICLE HISTORY \\ Received 11 September 2020 \\ Accepted 20 February 2021
}

\section{KEYWORDS}

App-Based Food Delivery Service, Consumer Behavior, COVID-19, Food Delivery Business, Pandemic

\section{Introduction}

Digital technologies are a crucial part of modern life. Consumers' lives, in today's ever-changing world, are inextricably intertwined with digital technologies. There may hardly be any part of our life that has not been touched by technology. In the last few decades, there has been a shift in our life from "bricks" to "clicks" - a transition from analog or physical dimension to the digital world. Increasing technological advancements, changes in lifestyle and growing consumer demands are now driving the worldwide extension of online businesses, even in the midst of the global COVID-19 crisis. Bangladesh is no exception in this regard. On its way to become "Digital Bangladesh", this country had 66.44 million internet users, 36 million social media users and 163 million mobile connections in January 2020 (Kemp, 2020). The country has witnessed more than twice the number of internet subscribers in the last five years (BTRC, 2020). As smartphones, internet connectivity, and personalized and interactive mobile apps have become more available and electronic payment methods have grown more reliable and convenient, consumers are now progressively utilizing online services in Bangladesh. Online transactions in Bangladesh have been increasing rapidly over the last few years. In 2016, the total investment of e-commerce in Bangladesh was $\$ 50$ million and in 2017, the e-commerce market was about $\$ 115$ million. It has been predicted by the E-Commerce Association of Bangladesh that in the

\footnotetext{
${ }^{1}$ Lecturer, Department of Business Administration, Bangladesh Army International University of Science \& Technology. Corresponding author: mohinurakter1989@gmail.com

${ }^{2}$ Institute of Business Administration (IBA), University of Dhaka
} 
upcoming years, the e-commerce market will be more than $\$ 70$ billion (Neger $\&$ Uddin, 2020). Ordering food online has become a popular trend in the country in recent years through which simply using apps on their phone, people can have food from restaurants of their choice delivered right at their doorsteps (Kader, 2020; Muntasir, 2019). An activity in which the food distribution service company performs the role of an intermediary between the restaurants and customers is popularly known as home delivery. Mobile phone applications have made home delivery services even more crucial due to the consumer's preference for the right product at the right time and in the right condition. The application of food delivery apps has completely changed the scenario of food industry in Bangladesh. Food delivery apps allow consumers to order their favorite food from a wide range of restaurants at their convenient time and location (Belanche, Flavián, \& Pérez-Rueda, 2020). In 2019 when corona had not hit the world yet, the market of online food delivery business in Bangladesh reached sales worth $\$ 10$ million, with more than 25,000 orders of food having been delivered every day on average. However, this market, which was estimated to cross $\$ 5$ billion by 2025 (Kader, 2020; Muntasir, 2019), faced a major crash when the COVID-19 pandemic hit the country and disrupted everyone's lives. In December of 2019, COVID-19 was first detected in Wuhan, China and in a little time span it had spread out globally. The outbreak had then been declared as a pandemic by the World Health Organization (WHO) (Neger \& Uddin, 2020). The outbreak of COVID-19 has not only driven severe economic consequences across the globe but also drawn dramatic changes in how businesses act and consumers behave (Donthu \& Gustafsson, 2020). Increase in poverty and inequalities is evident throughout the world, especially in underdeveloped and developing countries (UNDP, 2020). When the lockdowns were imposed in March prohibiting public gatherings, people were bound to stay at home and maintain social distancing while the restaurants had to close both their dining and takeout services. The movement of people across nations had been limited. As a result, online food orders faced drastic falls, dropping by 75 to 80 percent just in the first ten days of the lockdown. Despite various lucrative offers like discounts and free delivery made available to the consumers, the readymade food item delivery companies suffered a huge loss of business (Wardad, 2020). However, as months went by, consumers adapted to the new normal situation and started to rely more on online shopping. Consumers gradually started using food delivery services by putting their trust in the health and safety precautionary measures adopted by the food delivery companies and the restaurants. In fact, Uber Eats and Foodpanda in Bangladesh started contactless delivery in which the deliveryman leaves the food at the customers' doors and payment is made electronically (EHL Insights, 2020).

Even though app-based food delivery is now a trending concept in Bangladesh, little is known about the behavioral pattern of consumers regarding the application of these apps during the pandemic. Therefore, it is crucial for practitioners and academics to more readily comprehend the nature and patterns of consumer behavior in terms of online food delivery apps. This paper examines the different factors responsible for the shifts in consumer behaviors during the COVID-19 crisis in terms of ordering food online, especially through different local and international food delivery apps, between March and August of 2020.

The initial section of the paper explains the online food delivery service concept, the use of food delivery apps in Bangladesh and how the consumer behavior regarding food delivery apps has evolved during the COVID-19 pandemic. The literature review section then discusses the online food delivery process and the current scenario of the consumers' behavioral pattern about the online food delivery apps. Thereafter, the research methodology section describes the data collection method and the findings and the analysis section presents the main ideas derived from the results and their implications for management. The final part of the paper describes the limitations of the study and suggests the future scope of research in this rising field.

Overall, this paper contributes to the existing body of knowledge by clarifying which psychological factors have encouraged customers to use food delivery apps and how the consumer behavior has undergone dramatic changes during COVID-19 pandemic. (Belanche et al., 2020). To achieve this objective, the following six research questions have been formulated. 
Table 1: Research Questions Used in the Research

\begin{tabular}{ll}
\hline Research Question 1 (RQ1) & $\begin{array}{l}\text { Did people order food online, particularly via food delivery apps, during } \\
\text { the COVID-19 pandemic? }\end{array}$ \\
\hline Research Question 2 (RQ2) & $\begin{array}{l}\text { If not, what factors deterred consumers from ordering food from the } \\
\text { app-based food delivery businesses during the pandemic? }\end{array}$ \\
\hline Research Question 3 (RQ3) & $\begin{array}{l}\text { If yes, what factors motivated consumers to order food from the app- } \\
\text { based food delivery businesses during the pandemic? }\end{array}$ \\
\hline Research Question 4 (RQ4) & How frequently did consumers order food from the app-based food \\
& delivery services every month? \\
\hline Research Question 6 (RQ6) & Did the ordering frequency of the consumers vary over the months? If \\
& so, why? \\
& Did consumers find it morally right or wrong to order food online \\
\hline
\end{tabular}

\section{Literature Review}

New digital technologies are highly embraced by consumers in their life and this has transformed consumers' behavior immensely (Bucko, Lukáš, \& Martina, 2018). Technology can be defined as a combination of knowledge used to perform different types of activities and solve various problems. Today's marketplace and global economy are being highly influenced and even shaped by technology, which can create possible barriers and opportunities for both consumers and sellers (Fullerton, Bisschoff, \& Neale, 2016). Moreover, technology changes (i. e. improves or worsens) customer relationships with brands or services both emotionally and transnationally (Schiffman, Wisenblit, \& Kumar, 2018).

There are lots of uncertainties and challenges that organizations worldwide face every day and that affect the economies both directly and indirectly (Jarus, 2020). In the recent times, the most projected scenarios have been defied by the unprecedented consequences of COVID-19 (CarlssonSzlezak, Reeves, \& Swartz, 2020). Widespread damage to the global economy has already been caused by COVID-19; many countries have shut down their offices, businesses, even stock markets. Many major social events got cancelled throughout the world. Overall, the pandemic has negatively affected consumptions of various products (Ozili \& Arun, 2020). Consumer behavior has changed drastically with the eruption of COVID-19 and prompted businesses to reach even their most loyal brick-andmortar consumers in the digital space. Businesses have been forced to formulate novel solutions to adapt to the new normal (Carnevale \& Hatak, 2020). Due to the sophistication of the modern economies and digital technologies, marketers are attaching more importance to providing consumers with added value through swift online service and as a result, food delivery apps are gaining more attention from a socioeconomic perspective. Business platforms which are not responsible for the preparations of food but provide order services, payment and monitoring of the processes are known as online food delivery services (Pigatto, Machado, Negreti, \& Machado, 2017). The primary reasons behind the rising popularity of online food delivery services are the increasingly changing and fast-paced lifestyles of urban residents, convenience, various payment options and attractive promotional offers.

Many studies conducted in the area of online food delivery apps have found that with the increasing number of smartphone and internet users and the rise in dual-income households in the growing urban population in Bangladesh, the use of food delivery apps has become a routine work now, especially in the major cities such as Dhaka and Chattogram. Online food delivery businesses offer service through which customers can place orders over the Internet. In this business, people order food via phone calls, social media sites or website and wait for the deliveryman to deliver the food right at their doorstep. In app-based food delivery business, people place orders by using an app and a delivery man associated with that app delivers the food at the predetermined location, as shown in figure 1. 

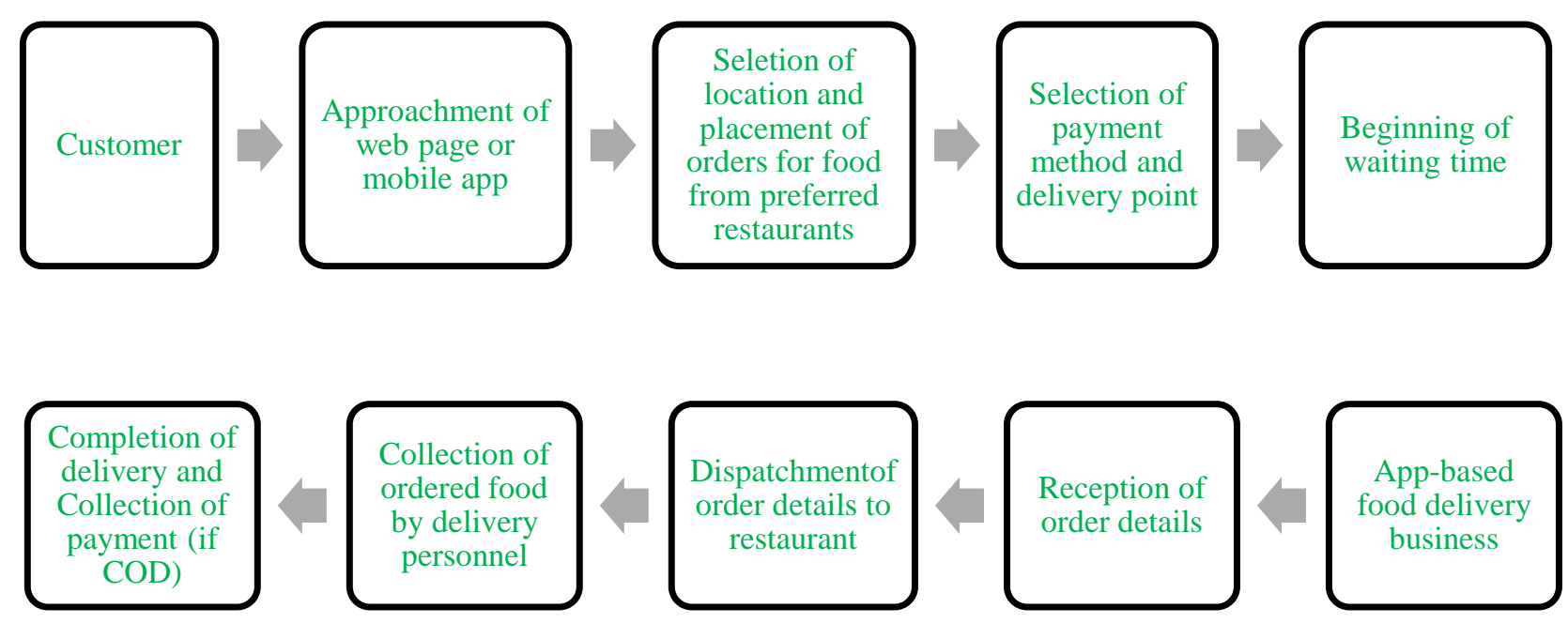

Figure 1: Food Order and Delivery Process

App-based food delivery services started their journey in Bangladesh with a local startup named HungryNaki in mid-2013, followed by Foodpanda joining the competition in late 2013 (Ahmed \& Ahmed, 2018; Muntasir, 2019). Soon more local and international ventures e.g. Pathao Food, Uber Eats, Shohoj Food and e-Food entered the market of online food delivery service in later years. All these businesses were thriving at excellent speeds until the coronavirus pandemic limited people's movement across the country. Behavioral changes among consumers became evident as they had to stay confined indoors and maintain control on their household hygiene by limiting what crossed the boundary of their house (Pollard \& O'Neill, 2020). Furthermore, as per several articles, various restaurants had to shut down at the beginning of the COVID-19 pandemic, which is also a reason for the decline in online food orders. The number of restaurants enlisted with the food delivery apps like Foodpanda and Pathao Food significantly dropped as most of their kitchen staffs went back to their hometowns at the initial stage of the lockdown and some restaurants were facing inventory issues including supply chain restrictions due to the outbreak (Chowdhury \& Haider, 2020). To gain consumers' attraction, app-based food delivery businesses provided consumers with various offers such as exemption of delivery charge but unfortunately, those offers failed to stop the drastic fall (Wardad, 2020). After the lockdown was lifted, the scenario changed a little with many consumers deciding to use their service on a limited basis, partly because no clear evidence was found regarding the transmission of the virus through food or food packaging (Hussey, 2020; WHO, 2020).

While several studies have analyzed in their research the effects of COVID-19 on people's lives (Heleem, Javaid, \& Vaishya, 2020), food safety and food security around the world (Dev \& Kabir, 2020; Kinsey, Kinsey, \& Rundle, 2020; Rizoua, Galanakisa, Aldawoudb, \& Galanakis, 2020) and the overall delivery service during the global crisis (Dishman, 2020), little work has been done, except for some journal and newspaper articles (Amit, 2020; Hussy, 2020; Nguyen \& Vu, 2020; Pollard \& O'Neill, 2020; Wardad, 2020; Zaman, 2020) that reached no indisputable conclusion, to identify the specific changes in consumer behaviors in terms of ordering food online during the pandemic, especially from the perspective of Bangladesh. Even though the importance of app-based food delivery is rising, the practical evidence on how consumer behavior for app-based food delivery in Bangladesh is missing. Only a limited number of empirical studies have tried to explore the consumer behavior for app-based food delivery in Bangladesh during COVID-19. Newspapers in Bangladesh offered updates on the market scenario of app-based and on-demand food delivery service businesses but the factors that are solely responsible for the changes in consumers' behavioral patterns over the period of six months (March to August) are yet to be found out. Thus, it is important to have analyses that consider exploring consumer behavior in terms of app-based food delivery in Bangladesh during COVID-19. 
The following theoretical framework was designed to lay the foundation of this study.

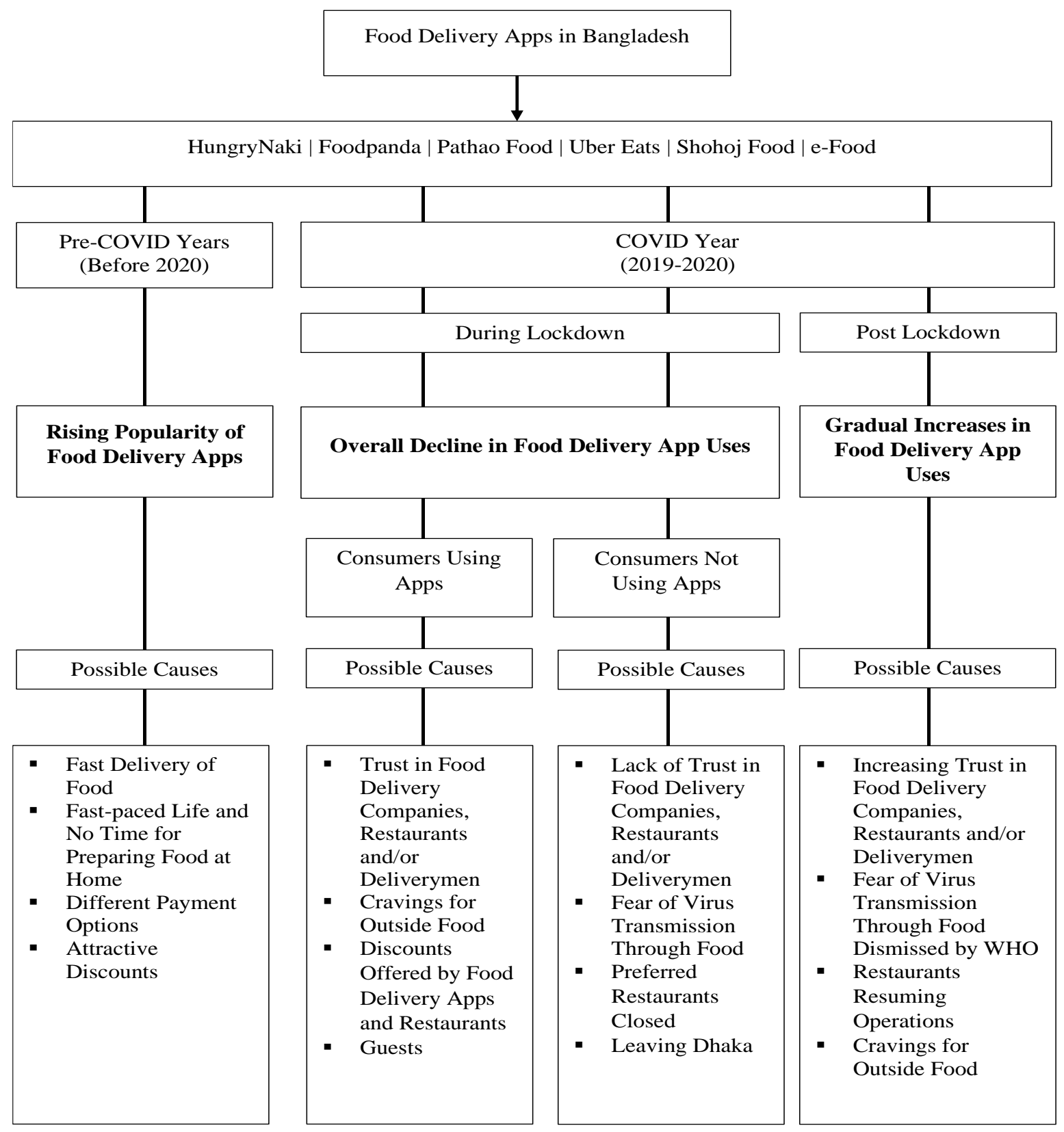

Figure 2: Theoretical Model for the Research

\section{Research Objective}

The primary objective of this research is to have a better understanding of consumer behaviors in terms of using online food delivery apps to order food during the COVID-19 pandemic. While several studies have been conducted in countries outside Bangladesh in this regard, significant research work has yet to be done identifying the specific factors that triggered certain behaviors in consumers in the face of a terrible global crisis. This research, therefore, aims to study behaviors of the consumers in Bangladesh with respect to ordering foods from the app-based food delivery businesses during the pandemic. 


\section{Research Methodology}

To carry out the research on how consumers in Bangladesh behaved during the COVID-19 pandemic in terms of ordering food from app-based food delivery businesses, data were collected from both primary and secondary sources.

\section{Primary Data Collection - Survey Questionnaire}

To collect data from primary sources, a survey questionnaire with the following structure was designed.

A survey questionnaire was designed with seventeen questions.

Six questions were created to obtain demographic information.
Eleven questions were created to gain original insights into consumer behaviors in terms of ordering food online in the time frame of six months (from March to August of 2020).

All those eleven questions were designed to understand what factors encouraged or discouraged consumers to order food online from apps during the Corona outbreak. The questions were also aimed to learn how much on average those who used the food delivery apps spent to order food online every month, how frequently they did so and whether the frequency of ordering food varied from month to month.

Those eleven questions were designed on the basis of the six research questions included in the earlier section.
Those eleven questions were divided into two sections

(except for one question that asked both groups of respondents whether they had ordered food online at any point during the COVID-19 pandemic).
One section was for those who availed services from online food delivery apps during the pandemic.
The other section was for those who didn't order from online food delivery apps during the pandemic.

Figure 3: Survey Questionnaire Structure

\section{Primary Data Collection - Participant Sampling}

To find the sample of the study, two different sampling methods were used - stratified random sampling and snowball sampling. For stratified random sampling, seven online groups on Facebook were chosen where the group demographic comprised people from diverse backgrounds (as evidenced by the sample description in table 1). The survey questionnaire was published on the feed of those groups and invited interested group members to fill it up. For snowball sampling, people who participated in the survey were asked to share the questionnaire with others. The primary reason the authors decided to use online groups on Facebook in order to circulate the survey was that social media users, oftentimes, are more likely to avail online food delivery services as these users are heavily influenced by the online promotional activities of the food delivery companies on various social media platforms. Moreover, 
social media users often share their experiences and opinions on platforms like Facebook that, in turn, influence consumer trust and buying behaviors to a great extent (Singh, R. K. \& Verma, H. K., 2020).

Due to time constraint, the survey questionnaire was kept open to responses for five days during which 552 people, in total, submitted their responses to the survey.

\section{Primary Data Collection - Sample Description}

Following is the description of the sample of 552 respondents who participated in the sixteen-question online survey (Table 1):

Table 1: Description of the Sample That Participated in the Online Survey

\begin{tabular}{|c|c|c|}
\hline \multirow[t]{3}{*}{ Gender of the respondents } & Female & $35.5 \%$ \\
\hline & Male & $63.9 \%$ \\
\hline & Other & $0.6 \%$ \\
\hline \multirow[t]{5}{*}{ Age group of the respondents } & $18-22$ & $23.2 \%$ \\
\hline & $23-28$ & $54.8 \%$ \\
\hline & $29-35$ & $14.8 \%$ \\
\hline & $35-45$ & $3.9 \%$ \\
\hline & $45+$ & $3.2 \%$ \\
\hline \multirow[t]{9}{*}{ Location of the respondents } & Dhaka & $80 \%$ \\
\hline & Chattogram & $11.5 \%$ \\
\hline & Sylhet & $0.5 \%$ \\
\hline & Rajshahi & $2 \%$ \\
\hline & Cumilla & $2.5 \%$ \\
\hline & Barishal & $1 \%$ \\
\hline & Khulna & $2 \%$ \\
\hline & Mymensingh & $0.5 \%$ \\
\hline & Rangpur & $0 \%$ \\
\hline \multirow{7}{*}{$\begin{array}{l}\text { Employment status of the } \\
\text { respondents }\end{array}$} & Employed - Full-time & $33.5 \%$ \\
\hline & Employed - Part-time & $7.7 \%$ \\
\hline & Self-employed & $7.7 \%$ \\
\hline & Freelancer & $5.8 \%$ \\
\hline & $\begin{array}{l}\text { Unemployed (Without a job but available } \\
\text { to work) }\end{array}$ & $7.1 \%$ \\
\hline & $\begin{array}{l}\text { I am a student and am currently not } \\
\text { working }\end{array}$ & $35.5 \%$ \\
\hline & Other (e.g. homemaker) & $2.7 \%$ \\
\hline \multirow{7}{*}{$\begin{array}{l}\text { Average monthly household } \\
\text { income of the respondents }\end{array}$} & Tk $0-30,000$ & $14.2 \%$ \\
\hline & Tk 30,001-50,000 & $11.6 \%$ \\
\hline & Tk 50,001-70,000 & $14.2 \%$ \\
\hline & Tk 70,001 - 100,000 & $16.8 \%$ \\
\hline & Tk 100,001-150,000 & $18.1 \%$ \\
\hline & Tk 150,001-200,000 & $10.3 \%$ \\
\hline & Tk 200,000+ & $14.8 \%$ \\
\hline
\end{tabular}




\begin{tabular}{lll}
\hline Whether respondents who are & Yes & $89.7 \%$ \\
$\begin{array}{l}\text { students and/or employees } \\
\text { worked from home during the }\end{array}$ & No & $10.3 \%$ \\
pandemic & & \\
\hline
\end{tabular}

\section{Secondary Data Collection}

To collect data from secondary sources, exhaustive reviews were conducted of the many digitally available national and international academic articles, journal articles and newspaper and magazine articles that explored this area of research. Local newspapers were reviewed to a great extent to gather recent data on the market scenario of the app-based food delivery businesses in the pandemic.

\section{Findings and Analysis}

\section{RQ1: Ordering Food Online During the COVID-19 Pandemic}

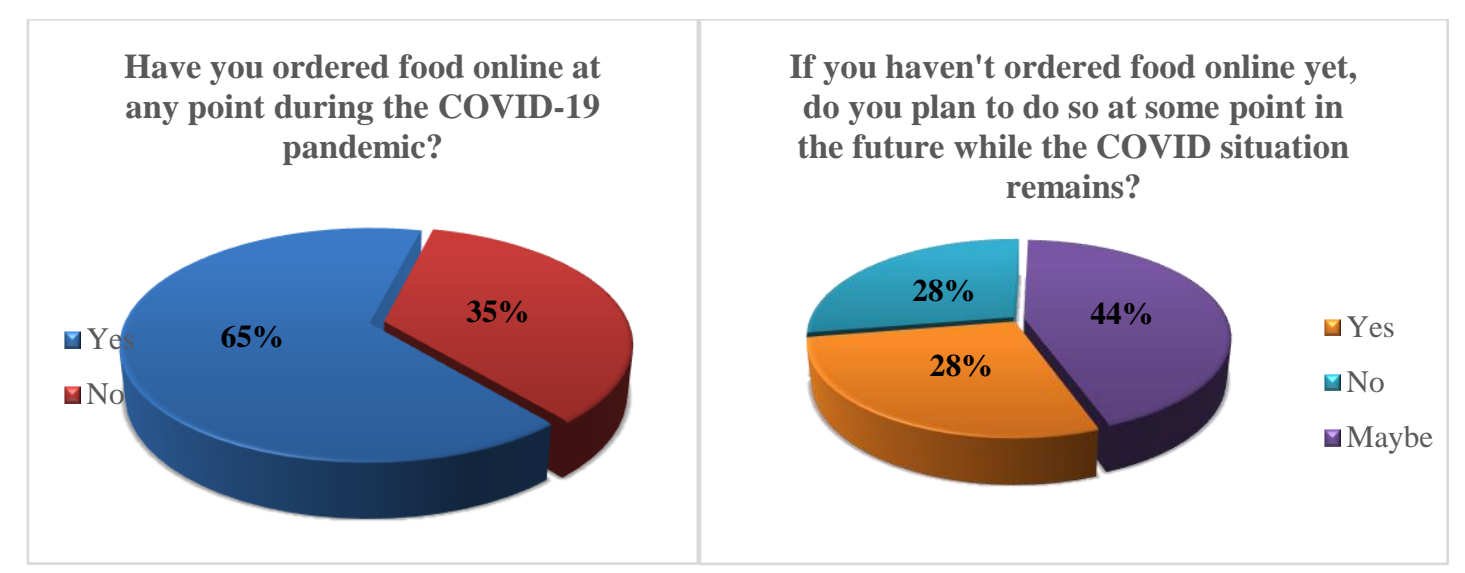

(Adapted from the online survey)

(Adapted from the online survey)

Figure 4: Responses to the survey question 'Have you ordered food online at any point during the COVID-19 pandemic?'
Figure 5: Responses to the survey question 'If you haven't ordered food online yet, do you plan to do so at some point in the future while the COVID situation remains?'

Out of the 552 respondents, when asked whether they ordered food online between March and August in 2020 during the COVID-19 pandemic, nearly 65\% (359 in number) answered 'yes' and the rest 35\% (193 in number) 'no'. However, when these 35\% respondents were asked if they had any plans to order food online in the upcoming days of the pandemic, 28\% said 'yes' and $44 \%$ said 'maybe'; only the rest of the $28 \%$ respondents, approximately 54 out of 552 , were absolutely sure they would not order food online by any means as long as the country remains plagued by Corona. Although a small percentage (around 10\% of 552 respondents), this group of consumers cares, more than anything, about the health and safety of their family and friends as well as of themselves; therefore, even if they have the purchasing power and/or live in areas where online food delivery businesses operate, they will refrain from making any buying decisions that might affect their health and safety directly or indirectly. According to one such respondent, "I am not going to order food in this pandemic. I just don't trust the people concerned with the entire process. And I don't want to die trusting them." 
Food Delivery Businesses Consumers Took Service From During the COVID-19 Pandemic

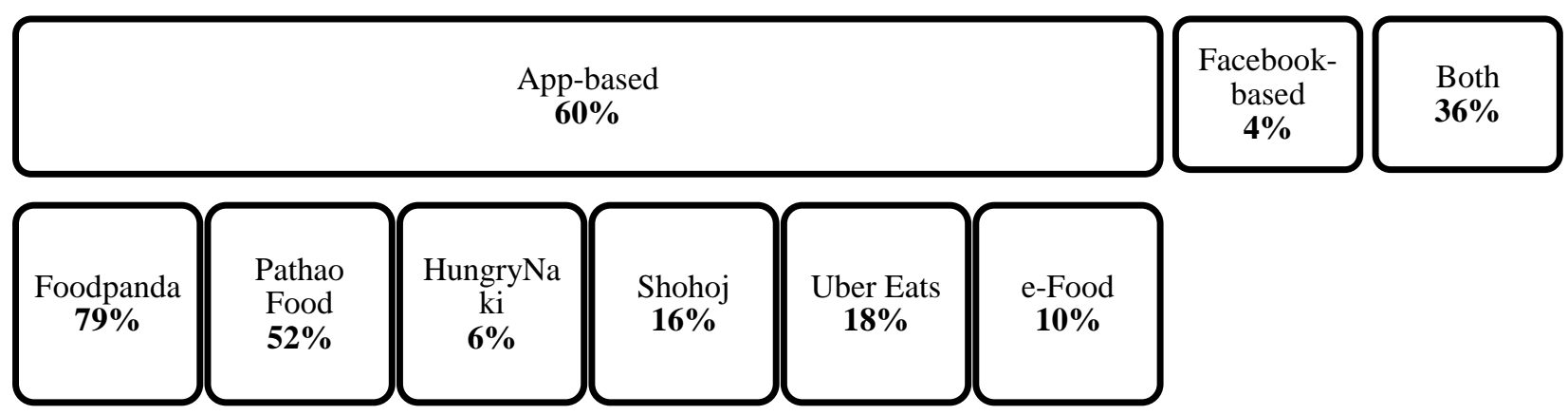

(Adopted from the online survey)

Figure 6: Frequency of consumers' orders for food delivery through apps

On the other hand, 359 respondents of the survey ordered food between March and August in 2020, availing services from app-based food delivery businesses (60\%), Facebook-based food delivery businesses $(4 \%)$ or both $(36 \%)$, suggesting that in total, $96 \%$ or 345 respondents used food delivery apps to order food online. According to the survey results, Foodpanda was most widely used (79\%) by the respondents, followed by Pathao Food (52\%). These figures signify that consumers put their trust in those two brands and kept using their services even in the time of the pandemic. Such unwavering trust and the resultant behavior from this particular group of consumers can be attributed to the strict policies having been adopted by the two brands. As per Ambareen Reza, CEO of Foodpanda Bangladesh:

At a time like this, we have been proactively reaching out to riders on preventive measures for Covid-19; providing the entire fleet of riders across Bangladesh with facemasks and hand sanitizers; we are also in the process of procuring PPE as mandated by the government. Besides, riders have been undergoing temperature screening daily at the hub offices before commencing work, and because of this, they feel safe and are willing to work for us (Chowdhury \& Haider, 2020).

Moreover, even though Uber Eats discontinued their operation in Bangladesh in June ("Uber Eats Closing Down in Bangladesh", 2020) and e-Food started their operation in the same month ("Evaly Launches Food Delivery Service 'e-food', 2020), a good number of consumers, as per the survey findings, used their services during the pandemic - 18\% respondents used Uber Eats and 10\% e-food mostly because of their brand value (for Uber Eats) and discount offers (for e-food).

Average Amount Consumers Spent on Food Ordered via Apps Every Month During the COVID-19

Pandemic

\begin{tabular}{lcccc}
\hline Tk 0-1,000 & Tk 1,001-2,000 & Tk 2,001-3,000 & Tk 3,001-5,000 & Tk 5,001+ \\
\hline $49 \%$ & $27 \%$ & $14 \%$ & $4 \%$ & $6 \%$ \\
\hline
\end{tabular}

(Adopted from the online survey)

Figure 6: Average amount spent by consumers on food delivery app services every month during the pandemic

However, even though the percentage of consumers who kept using food delivery services, especially the app-based ones, amid the pandemic may seem high, the average amount they normally spent every month before corona on food ordered via apps definitely decreased during the pandemic. Almost half the respondents (49\%) spent less than Tk 1,000 on average every month during the pandemic, implying 
that most consumers had misgivings while making their buying decisions. The second largest group of respondents (27\%) spent between Tk 1,001 and Tk 2,000 and only 6\% spent more than Tk 5,001 on average every month.

\section{RQ2: The Reasons Why Consumers Did Not Order Food Online During the Pandemic}

A large section of the 193 respondents who did not avail online food delivery services between March and August in 2020 during the pandemic attributed their decision to their lack of confidence in the precautionary measures taken by the restaurants, the food delivery companies and/or the food deliverymen $-42 \%$ agreed and $33 \%$ strongly agreed that they were not sure the food deliverymen were following all the necessary safety measures while making the deliveries from restaurants to houses; $46 \%$ agreed and $35 \%$ strongly agreed that they were not sure the restaurants were following all the necessary safety measures while preparing the food and $40 \%$ agreed and 35\% strongly agreed that they were not sure the food delivery companies had provided their deliverymen with enough training before sending them to work.

Table 2: Factors that influenced the buying behaviors of the consumers who did not order food online during the

\begin{tabular}{|c|c|c|c|c|c|}
\hline & $\begin{array}{l}\text { Strongly } \\
\text { disagree }\end{array}$ & Disagree & Neutral & Agree & $\begin{array}{l}\text { Strongly } \\
\text { agree }\end{array}$ \\
\hline $\begin{array}{l}\text { You weren't confident that the deliverymen } \\
\text { would follow all the safety precautions }\end{array}$ & $4 \%$ & $4 \%$ & $17 \%$ & $42 \%$ & $33 \%$ \\
\hline $\begin{array}{l}\text { You weren't confident that the restaurants } \\
\text { would maintain all the safety precautions }\end{array}$ & $7 \%$ & $4 \%$ & $8 \%$ & $46 \%$ & $35 \%$ \\
\hline $\begin{array}{l}\text { You weren't confident that the food delivery } \\
\text { companies had trained their deliverymen well in } \\
\text { following all the safety precautions }\end{array}$ & $4 \%$ & $7 \%$ & $18 \%$ & $40 \%$ & $31 \%$ \\
\hline $\begin{array}{l}\text { Most or all the restaurants you usually order } \\
\text { food from through the apps were closed during } \\
\text { the pandemic, especially during the lockdown }\end{array}$ & $7 \%$ & $22 \%$ & $32 \%$ & $32 \%$ & $7 \%$ \\
\hline $\begin{array}{l}\text { You didn't know for sure whether the virus gets } \\
\text { transmitted through food }\end{array}$ & $11 \%$ & $20 \%$ & $13 \%$ & $36 \%$ & $20 \%$ \\
\hline You left Dhaka when the lockdown started & $57 \%$ & $11 \%$ & $15 \%$ & $11 \%$ & $6 \%$ \\
\hline
\end{tabular}

This points to the gap in trust that the restaurants and the food delivery businesses in Bangladesh failed to fill during the pandemic, leading them to loss of consumers. According to one respondent:

I didn't order food online mainly because, the delivery personnel come in contact with multiple people throughout the process of delivering a single order, starting from the customers, restaurant workers and doorman. They deliver so many orders every day and come in contact with so many people. Their chance of being infected and carrying the virus is extremely high. Moreover, I have noticed them on the road to be in rush to deliver one order to grab the next. It made me doubt their sense of responsibility to take enough necessary precautions to stop the speed of the virus. Besides, in some cases they are also not aware of all the precautionary measures too. Finally, I would say I am a conscious citizen and I know I can protect myself by picking up my own food and groceries from restaurants and grocery stores respectively.

Interestingly enough, around 68\% of those 193 respondents said that they had left Dhaka at some point during the COVID lockdown, implying that they might have ordered food online if they had stayed in Dhaka during the entire pandemic. However, the facts that (i) almost all the app-based food delivery businesses have their operations in major cities (Chattogram, Sylhet, Rajshahi, Khulna, Cumilla, Cox's Bazar, Rangpur, Barishal, Jashore, Mymensingh) outside Dhaka and (ii) the respondents who had left Dhaka during the lockdown all lived in those locations and so, could order food online if they wanted 
to indicate that many of those respondents did not trust the restaurants, the food delivery companies and/or the food deliverymen enough to make a purchase during the pandemic.

Other factors that dissuaded this group of respondents from ordering food online include not being absolutely certain whether the virus gets transmitted through food; apparently, 56\% respondents from this group (36\% agreed and 20\% strongly agreed) just did not want to take any chance despite being aware that it " $\ldots$ is highly unlikely that people can contract COVID-19 from food or food packaging" (WHO, 2020, p. 1). A small percentage of respondents from this group did not order food online because their preferred restaurants were closed down during the pandemic, which suggests that the respondents might take services from food delivery businesses if their preferred restaurants resume their operation in the coming days of the pandemic.

\section{RQ3: Why Consumers Ordered Food Online During the Pandemic}

The largest section out of the 345 respondents (80\%) who availed app-based food delivery services between March and August in 2020 during the pandemic did so because staying home without being able to go outside for restaurant meals and hence, having only homemade meals for a long time made them crave outside food. They gave in to their cravings also because they $(75 \%)$ were confident in the health and safety measures they themselves were taking while receiving the deliveries.

Table 3: Factors that influenced the buying behaviors of the consumers who ordered food online via apps during the pandemic

\begin{tabular}{|c|c|c|c|c|c|}
\hline & $\begin{array}{l}\text { Strongly } \\
\text { disagree }\end{array}$ & Disagree & Neutral & Agree & $\begin{array}{c}\text { Strongly } \\
\text { agree }\end{array}$ \\
\hline $\begin{array}{l}\text { You were confident the deliverymen were } \\
\text { following all the safety precautions }\end{array}$ & $6 \%$ & $13 \%$ & $41 \%$ & $38 \%$ & $2 \%$ \\
\hline $\begin{array}{l}\text { You were confident that the restaurants were } \\
\text { maintaining all the safety precautions }\end{array}$ & $6 \%$ & $14 \%$ & $38 \%$ & $38 \%$ & $4 \%$ \\
\hline $\begin{array}{l}\text { You were confident that the food delivery } \\
\text { companies trained their deliverymen well in } \\
\text { following all the safety precautions }\end{array}$ & $6 \%$ & $14 \%$ & $34 \%$ & $41 \%$ & $5 \%$ \\
\hline You yourself followed all the safety precautions & $10 \%$ & $4 \%$ & $11 \%$ & $33 \%$ & $42 \%$ \\
\hline $\begin{array}{l}\text { You knew that the virus wasn't transmitted } \\
\text { through food }\end{array}$ & $14 \%$ & $9 \%$ & $31 \%$ & $36 \%$ & $10 \%$ \\
\hline $\begin{array}{l}\text { You wanted to contribute to the survival of the } \\
\text { restaurants and food delivery businesses during } \\
\text { the pandemic }\end{array}$ & $16 \%$ & $28 \%$ & $34 \%$ & $16 \%$ & $6 \%$ \\
\hline You were seriously craving for outside food & $6 \%$ & $4 \%$ & $10 \%$ & $36 \%$ & $44 \%$ \\
\hline You didn't have cooked food at your house & $27 \%$ & $32 \%$ & $21 \%$ & $13 \%$ & $7 \%$ \\
\hline You had guests at your house & $47 \%$ & $31 \%$ & $14 \%$ & $6 \%$ & $2 \%$ \\
\hline $\begin{array}{l}\text { Restaurants were offering a lot of discounts } \\
\text { during the pandemic }\end{array}$ & $19 \%$ & $22 \%$ & $29 \%$ & $22 \%$ & $8 \%$ \\
\hline
\end{tabular}

Respondents who used food delivery apps during the pandemic did so also because - $38 \%$ agreed and $2 \%$ strongly agreed that they were confident the food deliverymen were following all the necessary safety measures while making the deliveries from restaurants to houses; $38 \%$ agreed and $4 \%$ strongly agreed that they were confident the restaurants were following all the necessary safety measures while preparing the food and $41 \%$ agreed and 5\% strongly agreed that they were confident the food delivery companies had provided their deliverymen with enough training before sending them to work. What is interesting about these figures is, only a small percentage of respondents - from $2 \%$ to $5 \%$ - 'strongly' agreed that they were confident in the precautionary measures adopted by the food delivery businesses, the restaurants and the deliverymen, which implies that respondents who did put their trust in the abovementioned entities were still, deep in their subconscious, a little uncomfortable with their purchase decision. In other words, they were confident in the precautionary measures adopted by the food delivery businesses, the restaurants and the deliverymen mostly because they were confident in the precautionary measures they themselves were taking while receiving the deliveries. According to one 
respondent, "I feel like the delivery guys don't always follow all the precautions. I just used to sanitize the entire packaging once I had them delivered."

Moreover, 36\% respondents agreed and 10\% strongly agreed that their buying behavior was backed by the clearance from WHO that the coronavirus was highly unlikely to get transmitted through food or food packaging (WHO, 2020). As per one respondent:

When WHO said that there is no evidence to date of viruses that cause respiratory illnesses being transmitted via food or food packaging and that coronaviruses cannot multiply in food because they need an animal or human host to multiply, these statements were influential in my decision about ordering food online.

Almost 30\% respondents' buying behavior in the pandemic was also motivated by the various discounts and promotional rebates offered by the restaurants and the food delivery companies. During the pandemic, many restaurants were offering 30\% to 60\% discounts, free delivery and 'buy one get one' on their products to retain their buyers (Wardad, 2020). Some respondents ordered food because they did not have cooked food at home, there were guests in their house and/or they just wanted to help the restaurants and the deliverymen survive the ordeal of the pandemic.

\section{RQ4 and RQ5: Frequency of Ordering Food Online During the Pandemic}

While the 345 respondents of the survey ordered food via apps during the pandemic, the frequency of ordering varied from consumer to consumer and month to month. The chart above reveals how buying behaviors during the pandemic varied from consumer to consumer. $23 \%$ of the 345 respondents used food delivery apps once or twice a week, $28 \%$ once or twice a month and $15 \%$ several times a month. This group of consumers put a certain level of trust in the app-based food delivery businesses, the restaurants and the deliverymen while making their purchase decisions.

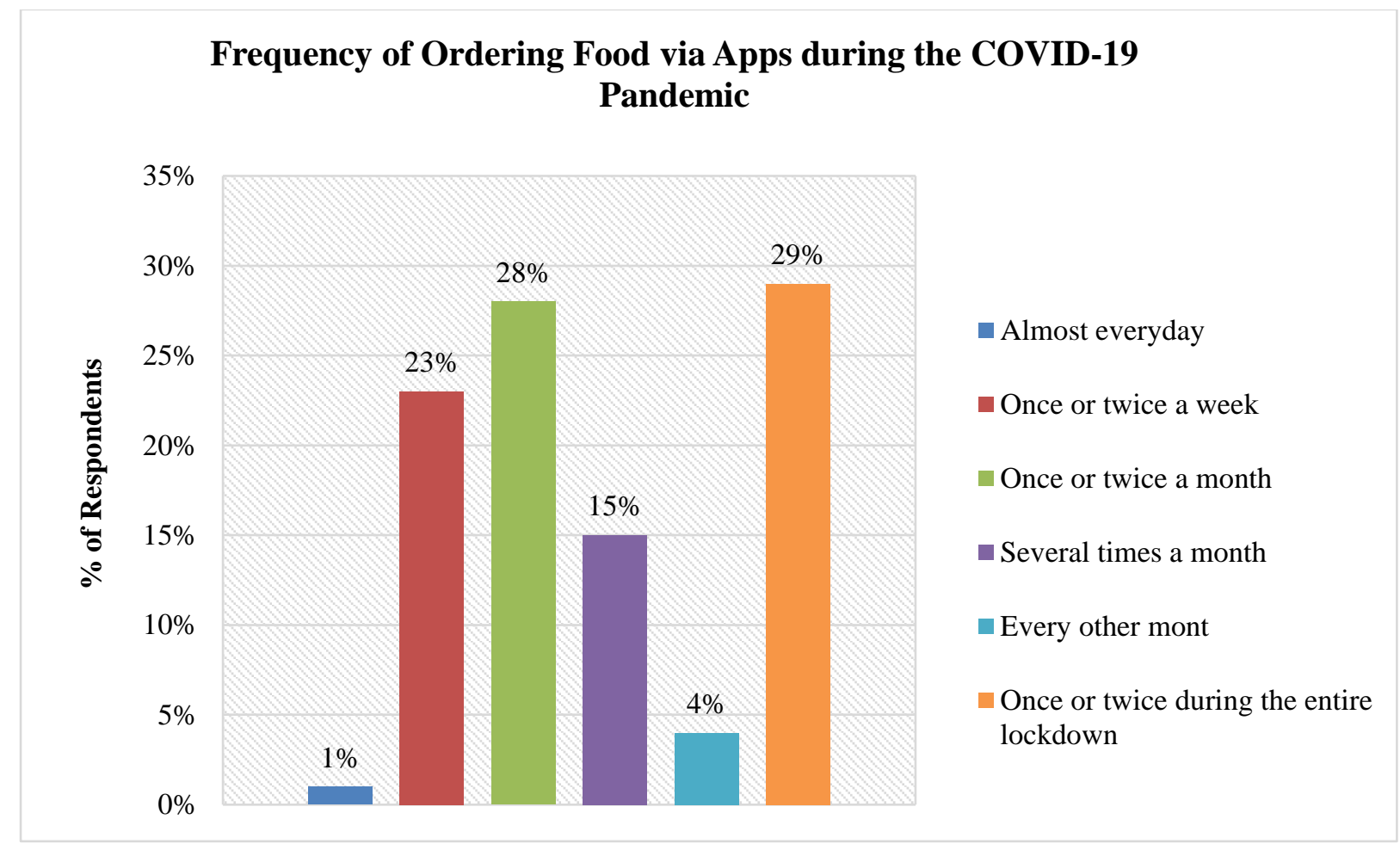

(Adopted from the online survey)

Figure 8: The consumer-to-consumer changes in the ordering frequency during the pandemic 
On the contrary, $29 \%$ respondents used food delivery apps once or twice during the entire lockdown. This special group of consumers ordered food via apps primarily because they couldn't resist their cravings for restaurant food after having only homemade meals for a long time during the pandemic.

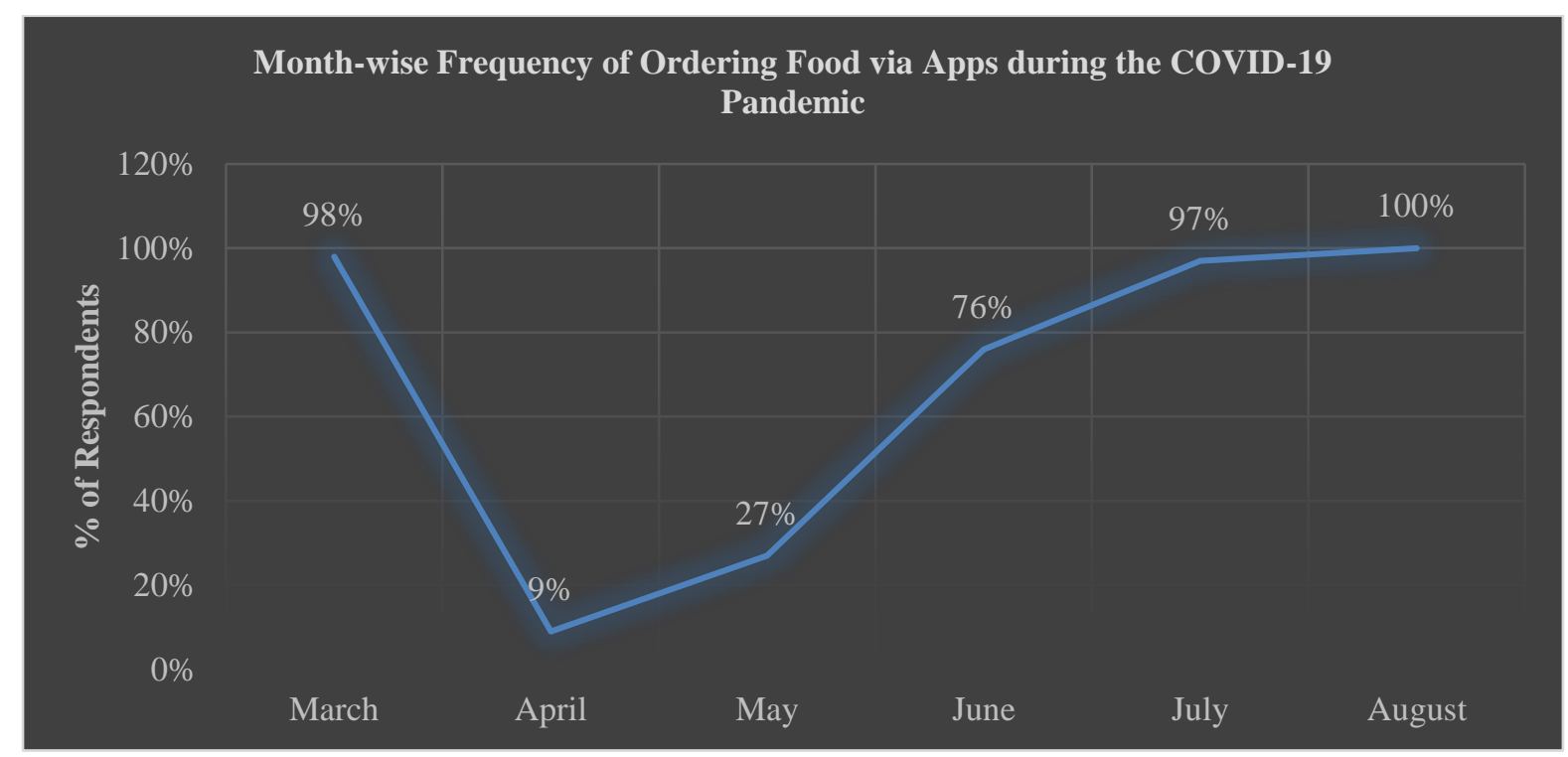

(Adopted from the online survey)

Figure 9: The month-to-month changes in the ordering frequency during the pandemic

The chart above represents how consumers' buying behavior during the pandemic varied from month to month. In March, when the COVID-19 situation was at its initial mild stage and the nationwide lockdown wasn't put into action, almost all the respondents (98\% of 345) were still using the food delivery apps, not realizing that Bangladesh would be severely affected by the virus in the coming days. So when the lockdown started, restaurants closed down in large numbers and people's fear spiked, most consumers decided not to use the food delivery apps; according to the survey results, only $9 \%$ respondents used food delivery in April. In May, some restaurants started offering takeaway service and WHO established that the coronavirus was highly unlikely to get transmitted through food or food packaging (WHO, 2020), so consumers started using the food delivery apps on a small level (27\% ordered food in April). When government decided not to extend the lockdown period after May, most restaurants resumed their operations and gradually, consumers started using the food delivery apps more (76\% ordered food in June, 97\% in July and 100\% in August). According to one respondent:

I personally didn't order food in the beginning of the pandemic because I didn't want to put the deliverymen at risk for delivering nonessentials. But now it feels like the situation's improved even though the numbers are crazy, so I'm ordering more often than I did when the lockdown started but still less than how much I'd order in precorona times.

\section{RQ6: Ordering Food Online During the Pandemic and Consumers' Moral Compass}

To understand whether their buying behavior was influenced, in any way, by their perception of morality in terms of using food delivery during the coronavirus pandemic, 359 respondents who ordered food online between March and August in 2020 were asked whether they thought ordering food online during the pandemic is morally right. While $55 \%$ of those 359 respondents answered 'yes' and 6\% 'no', it was not surprising to find that $35 \%$ respondents answered 'I am not sure'. 


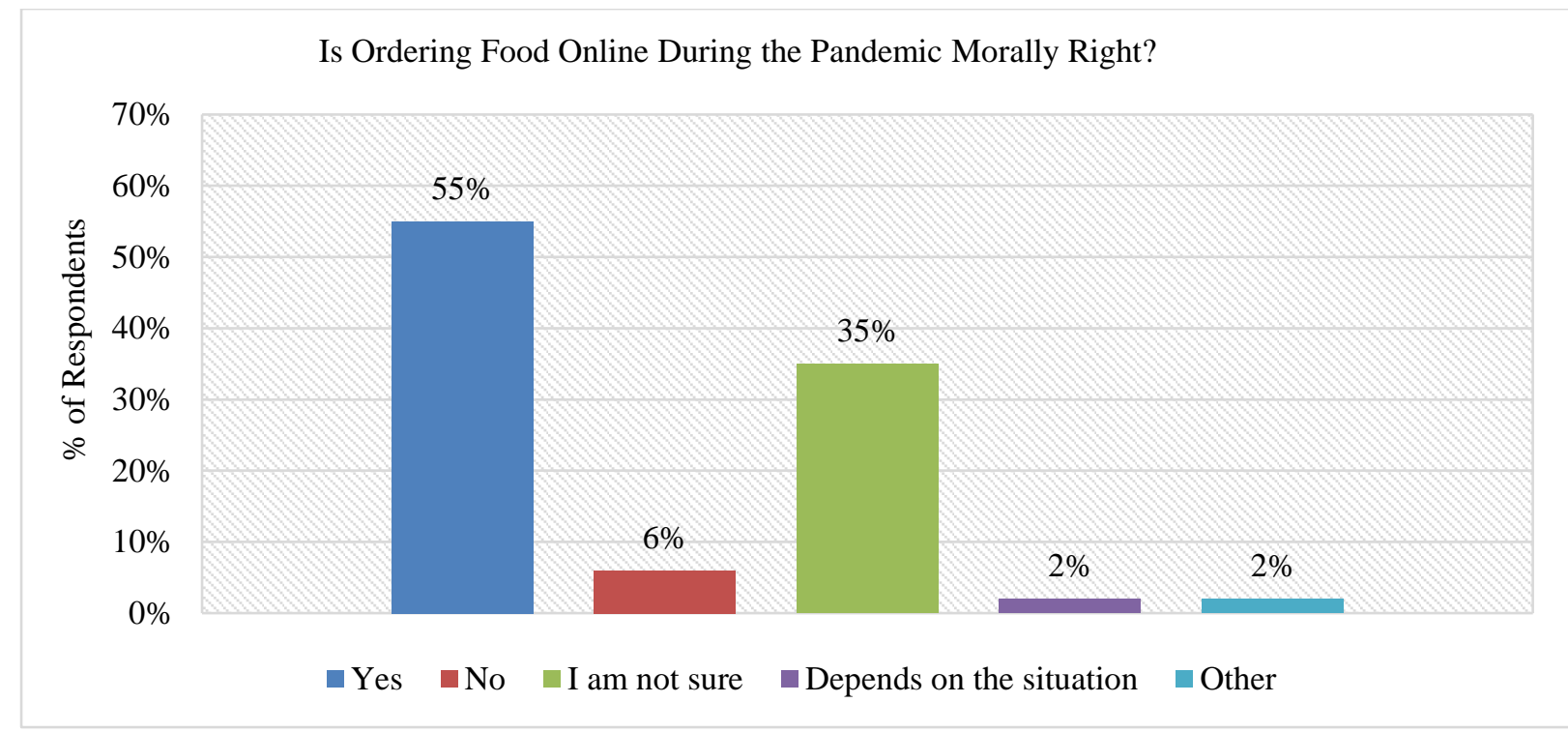

(Adopted from the online survey)

Figure 10: Responses to the survey question 'Do you think it is morally right to order food online during a pandemic?'

As reflected in the findings of the survey, a large part of the consumer population in Bangladesh does not even recognize that ordering food by using online food delivery businesses has anything to do with morality or ethics. An even larger part of the consumer base thinks that it is morally right to use food delivery service during a pandemic because, as per one respondent, "the businesses are operational and people's livelihood depends on it." But when a consumer orders food to help workers keep their jobs, it might mean she/he is paying them to risk their health (Bokat-Lindell, 2020). For some consumers $(2 \%)$, on the other hand, buying decisions and behaviors 'depend on the situation'. One respondent stated, "I think it's not a moral issue if someone orders food for regular consumption. But ordering food for celebrations is not right. Amid all these uncertainties, extravaganza should be avoided even if your income is not threatened." The most interesting part about the results of this survey question was that $6 \%$ respondents who actually ordered food online during the pandemic thought doing so is not morally right. These respondents might have had valid reasons to use food delivery service during the pandemic but their action pointed to the fact that consumers do not always behave rationally.

\section{Conclusion and Scope for Future Research}

The original idea behind this research was to explore the nitty-gritty of 'how' and 'why' the consumers in Bangladesh behaved in certain manners in respect of ordering food via apps during the COVID-19 pandemic. As per the findings of the study, consumer behaviors during the pandemic were largely influenced by psychological factors. Most consumers who used food delivery app services in this period (how) were motivated by their cravings as well as their confidence in the health and safety measures taken by themselves (why). Their perception that the food delivery businesses, the restaurants and the deliverymen were following strict precautionary measures played a great role in influencing their purchase decisions (why). On the other hand, consumers who refrained from using the food delivery apps (how) could not take any risks by placing their trust in the food delivery businesses, the restaurants and the deliverymen (why). Findings of the study also suggested that consumers' ordering frequency varied as their perceptions of the coronavirus associated risks and the resultant safety policies adopted by businesses changed over the months (why). Furthermore, as per the findings, in most cases, consumers' buying behaviors during the pandemic were not motivated by their sense of morality.

In future, in the event that the COVID-19 situation does not improve for another two years and/or another viral outbreak takes over the country, this study will help food delivery businesses, particularly the app-based services, and restaurants in Bangladesh take preemptive measures to handle the crisis. 
While the primary goal of the study has been accomplished substantially, several other aspects of the research subject should be considered for further studies. For this study, 552 respondents were part of the process, most of whom were, at least during the data collection phase, geographically located in Dhaka. Therefore, studies with a much larger sample and/or concentrating in regions outside Dhaka (e.g. Chattogram, Sylhet, Rajshahi, Khulna, Cumilla, Cox's Bazar, Rangpur, Barishal, Jashore, Mymensingh) where the app-based food delivery businesses have their operations should be carried out. Moreover, it will be interesting to see some comparative studies on how consumers in different cities behave in terms of ordering food online during the pandemic or whether consumers' buying behaviors during the pandemic vary with respect to local and foreign food delivery service apps. The idea of morality or ethics in the matter of using food delivery services during a pandemic can be a thought-provoking area of research, especially in the context of consumer behavior in Bangladesh.

\section{References}

Ahmed, J. U., \& Ahmed, A. (2018). Foodpanda: Changing the way Bangladeshi eat meals. Retrieved from https://www.researchgate.net/publication/322269467_Foodpanda_Changing_the_Way_Bangl adeshi_Eat_Meals

Amit, S. (2020, March 10). The future of on-demand food delivery and COVID-19. The Business Standard. Retrieved from https://tbsnews.net/panorama/future-demand-food-delivery-andcovid-19-54274

Bokat-Lindell, S. (2020, May 7). Is food delivery during the coronavirus pandemic ethical? The New York Times. Retrieved from https://www.nytimes.com/2020/05/07/opinion/coronavirusdelivery-food.html

Belanche, D., Flavián, M., \& Pérez-Rueda, A. (2020). Mobile apps use and WOM in the food delivery sector: The role of planned behavior, perceived security and customer lifestyle compatibility. Retrieved from doi: 10.3390/su12104275

Bucko, J., Kakalejčík, L., \& Ferencová, M. (2018). Online shopping: Factors that affect consumer purchasing behavior. Cogent Business \& Management, 5(1), 1-15.

Carlsson-Szlezak, P., Reeves, M., \& Swartz, P. (2020). What coronavirus could mean for the global economy. Harvard Business Review. Retrieved from https://hbr.org/2020/03/whatcoronavirus-could-mean-for-the-global-economy.

Carnevale, J. B., \& Hatak, I. (2020). Employee adjustment and well-being in the era of COVID-19: Implications for human resource management. Journal of Business Research, 116, 183-187.

Chowdhury, M. M., \& Haider, M. H. (2020, May 5). Restaurant business and a pandemic. The Daily Star. Retrieved from thedailystar.net/lifestyle/cover-story/news/restaurant-business-andpandemic-1899493

COVID-19 and food safety: Guidance for food business. (2020, April 7). World Health Organization. Retrieved from https://apps.who.int/iris/rest/bitstreams/1274400/retrieve

COVID-19 and the F\&B industry: Delivery services to the rescue. (2020). EHL Insights. Retrieved from https://hospitalityinsights.ehl.edu/covid-19-delivery-services

Dev, D. S., \& Kabir, K. H. (2020). COVID-19 and food security in Bangladesh: A chance to look back at what is done and what can be done. Journal of Agriculture, Food Systems, and Community Development. Advance online publication. https://doi.org/10.5304/jafscd.2020.094.008

Dishman, L. (2020, March 30). The delivery app landscape is changing and sustaining businesses during COVID-19. Retrieved from https://www.uschamber.com/co/good-company/launch$\mathrm{pad} /$ coronavirus-pandemic-food-delivery-businesses

Donthu, N., \& Gustafsson, A. (2020). Effects of COVID-19 on business and research. Retrieved from https://www.sciencedirect.com/science/article/pii/S0148296320303830?via\%3Dihub

Evaly launches food delivery service 'e-food'. (2020, June 17). Dhaka Tribune. Retrieved from https://www.dhakatribune.com/business/2020/06/17/evaly-launches-food-delivery-service-efood

Fullerton, S., Bisschoff, C. A., \& Neale, L. G. (2016). Technomarketing: An Assessment of the underlying structure concerning the perceived effectiveness of an array of technology-based 
marketing strategies. In J. G. Fowler, \& J. Weiser (Eds.), Reimagining: The power of marketing to create enduring value: Vol. 11. Society for marketing advances (pp. 547-557). DOI: https://societyformarketingadvances.org/resources/Documents/Resources/Conference\%20Pro ceedings/SMA2016_v11.pdf

Gunther, M. (2020, April 10). Is grocery delivery ethical during a pandemic? Retrieved from https://gen.medium.com/is-grocery-delivery-ethical-during-a-pandemic-144aee5f9a37

Heleem, A., Javaid, M., \& Vaishya, R. (2020). Effects of COVID 19 pandemic in daily life. Current Medicine Research and Practice, 10(2), 78-79.

Hussy, A. (2020, April 1). Food delivery in demand during COVID-19. Retrieved from https://kerry.com/insights/kerrydigest/2020/food-delivery-in-demand-during-covid-19

Jarus, O. (2020). 20 of the worst epidemics and pandemics in history. Live Science. Retrieved from https://www.livescience.com/worst-epidemics-and-pandemics-in-history.html.

Kader, R. (2020, February 4). The state of online food delivery in Bangladesh at the beginning of 2020: Subsidies make true demand hard to gauge. Retrieved from https://futurestartup.com/2020/02/04/online-food-delivery-in-bangladesh-subsidies-maketrue-demand-hard-to-gauge/

Kemp, S. (2020, February 17). Digital 2020: Bangladesh. DataReportal. Retrieved from https://datareportal.com/reports/digital-2020-bangaldesh

Kinsey, E. W., Kinsey, D, \& Rundle, A. G. (2020). COVID-19 and food insecurity: An uneven patchwork of responses. J Urban Health, 97, 332-335.

Muntasir, B. (2019, May 26). Meteoric rise of online food business. Dhaka Tribune. Retrieved from https://www.dhakatribune.com/business/2019/05/26/meteoric-rise-of-online-food-business

Neger, M., \& Uddin, B. (2020). Factors affecting consumers' internet shopping behavior during the COVID-19 pandemic: Evidence from Bangladesh. Retrieved from DOI: 10.17265/1537$1506 / 2020.03 .003$

Nguyen, T. H. D., \& Vu, D. C. (2020). Food delivery service during social distancing: Proactively preventing or potentially spreading coronavirus disease-2019? Disaster Medicine and Public Health. Retrieved from https://www.ncbi.nlm.nih.gov/pmc/articles/PMC7235311/

Ozili, P. K., \& Arun, T. G. (2020). Spillover of COVID-19: Impact on the global economy. SSRN Electronic Journal. Retrieved from https://www.researchgate.net/publication/340236487_Spillover_of_COVID19_impact_on_the_Global_Economy

Pigatto, G., Machado, J. G. d. C. F., Negreti, A d. S., \& Machado, L. M. (2017). Have you chosen your request? Analysis of online food delivery companies in Brazil. British Food Journal, 119(3), 639-657.

Pollard, M., \& O’Neil, C. T. (2020, April 30). How COVID-19 is impacting online food delivery platforms. Retrieved from https://www.citivelocity.com/citigps/how-covid-19-is-impactingonline-food-delivery-platforms/

Rizoua, M., Galanakisa, I. M., Aldawoudb, T. M. S., \& Galanakis, C. M. (2020). Safety of foods, food supply chain and environment within the COVID-19 pandemic. Trends in Food Science \& Technology, 102(8), 293-299.

Schiffman, L. G., Wisenblit, J., \& Kumar, S. R. (2018). Consumer behavior (12 ${ }^{\text {th }}$ ed.). Upper Saddle River, NJ: Pearson Education.

Singh, R. K., \& Verma, H. K. (2020). Influence of social media analytics on online food delivery systems. International Journal of Information System Modeling and Design (IJISMD), 11(3), $1-21$.

Uber Eats closing down in Bangladesh. (2020, May 19). The Daily Star. Retrieved from https://www.thedailystar.net/uber-eats-closing-down-in-bangladesh-1904089

Wardad, Y. (2020, March 30). Online food delivery business takes a big hit. The Financial Express. Retrieved from https://thefinancialexpress.com.bd/trade/online-food-deliverybusiness-takes-a-big-hit-1585541334

Zaman, K. T. (2020). Ambareen Reza of Foodpanda shares insights of the food delivery business. ICE Today. Retrieved from https://icetoday.net/2020/07/panda-to-the-rescue/ 